\title{
ResearchArticle
}

\section{Studies on phenological characters and yield attributes of rice genotypes at graded levels of phosphorus}

\author{
HIMANSHU PATEL, BRAJENDRA, V.N. MISHRA AND V.P. BHADANA
}

\begin{abstract}
SUMMARY
Phosphorus is one of the most limiting nutrients for plant growth in soil in both acidic and alkaline soils. To screen the genotypes for their P use efficiency and response to its application the genotypes need to be grown under different gradients so as to compare their performance under different regimes of $\mathrm{P}$ application. Therefore, low $\mathrm{P}$ plots were divided into 4 sub-plots with different gradients $\left(0,20,40\right.$ and $60 \mathrm{~kg} \mathrm{P}_{2} \mathrm{O}_{5} /$ ha, respectively). Results showed that at 0 (absolute control) level of $\mathrm{P}_{2} \mathrm{O}_{5}$, rice genotypes differed widely among all the phenological and yield attributing characters studied. Root length measured was recorded lowest for Mahsuri cultivar $(18 \mathrm{~cm})$ whereas highest root length at maturity stage was recorded for Vikas and Vasumati cultivars $\left(26 \mathrm{~cm}\right.$ each). At $20 \mathrm{Kg} \mathrm{P}_{2} \mathrm{O}_{5} /$ ha level, root length measured was recorded lowest for Mahsuri cultivar $(19 \mathrm{~cm})$ whereas highest root length at maturity stage was recorded for Akshaydhan cultivar (30 cm). At $40 \mathrm{Kg} \mathrm{P}_{2} \mathrm{O}_{5} /$ ha level, root length measured was recorded lowest for MTU 1010 cultivar (20cm) whereas highest root length at maturity stage was recorded for Vasumati cultivar $(30 \mathrm{~cm})$. Similarly At $60 \mathrm{Kg} \mathrm{P}_{2} \mathrm{O}_{5} /$ ha level, for plant height the values ranged from a low of $58 \mathrm{~cm}$ for Rp-bio- 226 cultivar to a high of $99 \mathrm{~cm}$ for Vardhan cultivar. Significant but not steep variations were noticed among cultivars for root length, flag leaf length and effective number of tillers characteristics at maturity stage.
\end{abstract}

Key Words : Phenological characters, Yield attributes, Rice genotypes, Phosphorus

How to cite this article : Patel, Himanshu, Brajendra, Mishra, V.N. and Bhadana, V.P. (2016). Studies on phenological characters and yield attributes of rice genotypes at graded levels of phosphorus. Internat. J. Plant Sci., 11 (2): 198-202, DOI: 10.15740/HAS/IJPS/ 11.2/198-202.

Article chronicle : Received : 02.02.2016; Revised : 09.04.2016; Accepted : 23.05.2016

\section{MEMBERS OF THE RESEARCH FORUM}

Author to be contacted :

HIMANSHU PATEL, Indira Gandhi Krishi Vishwavidyalaya, RAIPUR (C.G.) INDIA

Address of the Co-authors:

BRAJENDRA AND V.P. BHADANA, ICAR-Indian Institute of Rice

Research, HYDERABAD (TELANGANA) INDIA

V.N. MISHRA, Indira Gandhi Krishi Vishwavidyalaya, RAIPUR (C.G.) INDIA 